\title{
KEPRIBADIAN INTROVERT DALAM FOTOGRAFI EKSPRESI
}

\author{
Ngesti Limna Sari
}

Fakultas Media Rekam, Institut Seni Indonesia Yogyakarta

e-mail : ngesti.limnas@gmail.com

Diterima: 25 Agustus 2018. Disetujui : 6 November 2018. Dipublikasikan : 1 Desember 2018

bawah lisensi CC BY 4.0 (https://creativecommons.org/licenses/by/4.0/)

\begin{abstract}
ABSTRAK
Kepribadian manusia merupakan bentuk tingkah laku manusia berdasarkan sikap dan sifatnya. Kepribadian setiap manusia berbeda-beda, hal ini di pengaruhi oleh dua faktor utama yaitu, faktor internal dan eksternal. Carl Gustav Jung adalah seorang pencipta teori psikologi analitis membagi kepribadian manusia berdasarkan sikap jiwanya menjadi dua tipe yaitu introvert dan ekstrovert. Penciptaan dengan judul "Kepribadian Introvert dalam Fotografi Ekspresi" ini membahas mengenai kepribadian introvert pada manusia. Kepribadian introvert merupakan kepribadian manusia yang lebih cenderung fokus dengan dunia yang ada dalam dirinya sendiri dan membatasi dirinya dengan dunia luar sehingga dalam masyarakat umum, muncul penilaian yang kurang tepat. Sehingga muncul keinginan untuk memvisualkan bagaimana sebenarnya ciri-ciri kepribadian introvert dari sudut pandang seorang introvert dan teori mengenai kepribadian introvert. Media yang digunakan untuk penciptaan karya adalah fotografi ekspresi. Fungsi fotografi ekspresi adalah sebagai media ungkapan perasaan dan gagasan seorang fotografer. Proses digital imaging dilakukan dalam penciptaan karya untuk penambahan elemen dan objek pendukung sebagai media penyampai pesan, agar pesan yang ada pada foto bisa sampai kepada penikmat foto. Tujuan penciptaan ini adalah untuk menggambarkan bagaimana kepribadian manusia khususnya introvert dapat divisualisasikan melalui media fotografi ekspresi.
\end{abstract}

Kata kunci: fotografi ekspresi, introvert, kepribadian.

\section{ABSTRACT}

Human personality is a form of human behavior based on attitude and nature. The personality of every human being is different, this is influenced by two main factors, namely, internal and external factors. Carl Gustav Jung is a creator of analytical psychological theory dividing human personality based on his soul attitude into two types, namely introvert and extrovert. The creation of the title "Introverted Personality in Expression Photography" discusses introverted personality in humans. Introverted personality is a human personality that is more likely to focus on the world that exists in itself and limit itself to the outside world so that in the general public, an inappropriate assessment appears. So the desire arises to visualize how introverted personality traits actually are from the point of view of an introvert and the theory of introverted personality. The media used for the creation is expression photography. It's for a medium to express the feelings and ideas of a photographer. The digital imaging process is carried out in the creation of works for the addition of supporting elements and objects as message delivery media, so that the message on the photo can reach photo lovers. The purpose of this creation is to describe how human personality, especially introverts, can be visualized through the media of expression photography.

Kata kunci: expression photography, introvert, personality.

\section{PENDAHULUAN}

Awal ditemukannya fotografi, fungsi dasar dari fotografi adalah merekam suatu objek. Seiring dengan perkembangan zaman, teknologi fotografi di masa kini ikut berkembang kegunaannya dan mulai digunakan sebagai hobi mulai dari foto konsep, dokumentasi sehari-hari hingga sebagai media untuk 
menuangkan ide menjadi sebuah karya seni fotografi. Hal ini di mungkinkan bahwa fungsi fotografi sejauh ini sudah lebih dari sekedar menjadi alat atau media perekaman dokumentasi saja. Akan tetapi sudah menapak sebagai media untuk berkespresi dalam domain kesenian terutama yang bernuansa seni visual (Soedjono, 2006).

Ekspresi merupakan ungkapan batin, perasaan, atau gagasan seorang seniman. Seorang seniman akan membuat sebuah karya berdasarkan ciri khas yang ada pada diri seniman itu sendiri, sehingga nantinya karya tersebut bisa menjadi bentuk identitas diri. Selain sebagai media ekspresi, foto bisa menjadi media penyampai pesan. Cara yang paling mudah untuk menggambarkan maksud atau pesan dari sebuah foto misalnya dengan menunjukkan ciri khas objek atau penambahan properti yang berhubungan dengan objek, sebagai elemen pendukung. Kepribadian seseorang dapat berpengaruh besar terhadap hasil karya yang diciptakannya. Kepribadian setiap orang tumbuh berdasarkan dua faktor, yaitu faktor dari dalam dan dari luar. Faktor dari dalam telah dibawa sejak lahir ke dunia berupa bibit atau lebih sering disebut kepribadian dasar manusia. Sementara faktor dari luar adalah lingkungan sekitar manusia setelah lahir ke muka bumi seperti pengaruh lingkungan, pengaruh budaya, dan pengalaman pribadi atau orangorang di sekitarnya.

Pengelompokan kepribadian manusia menurut Carl Gustav Jung yaitu seorang pencipta teori psikologi analitis berkebangsaan Jerman bahwa berdasarkan sikap jiwanya, manusia dapat digolongkan menjadi dua tipe yaitu introvert dan ekstrovert. Menurut Jung, kesadaran manusia dalam mengadakan hubungan dengan dunia luar menunjukkan dua sikap utama, yaitu introvert dan ekstrovert. Seseorang dapat di katakan bersikap introvert jika sikap kesadaran seseorang mengarah ke dalam dirinya sendiri. Sementara sikap yang ekstrovert artinya sikap kesadaran yang mengarah ke luar dirinya, yaitu kepada alam sekitar dan manusia lain. Manusia yang mempunyai tipe sikap yang introvert umumnya mempunyai minat pokok pada dunia subjektif yang dijadikan sebagai asas-asas pertimbangan. Selain hal itu, orang dengan sikap ekstrovert umumnya mempunyai minat pokok kepada dunia luar dan menganggap dunia objektif sebagai nilai-nilai esensial dalam hidupnya (Prawira, 2013).

Penciptaan ini membahas mengenai kepribadian introvert karena dipengaruhi faktor internal dan eksternal. Secara internal, pencipta termasuk dalam golongan manusia dengan tipe kepribadian yang cenderung introvert sehingga bisa lebih memahami mengenai kepribadian introvert. Sedangkan faktor eksternal, dipengaruhi oleh ketertarikan terhadap karya visual 2 dimensi dengan kesan sepi, tenang, dan misterius seperti karya Vilhelm Hammershoi. Ketertarikan terhadap karya dua dimensi dengan kesan sepi, tenang dan misterius menjadi faktor eksternal dalam latar belakang timbulnya ide penciptaan ini. Pengalaman fenomenologis bersifat personal dan eksistensial. Orang- orang yang berbeda, kendati mengalami suatu kejadian yang sama, tak mungkin mempunyai pengalaman yang seragam. Maka, sebuah foto selalu melahirkan sensasi unik dan individualisti (Svarasjati, 2013)

Pribadi introvert akan sangat menikmati kenyamanan dalam sepi dan ketenangan. Masyarakat pada umumnya akan beranggapan bahwa orang introvert adalah orang yang pemalu, tertutup, tidak mau bersosialisasi, dan suka menyendiri. Bagi orang introvert menyendiri dan menyelami pikiran sendiri menjadi hal yang menyegarkan dibandingkan harus berkumpul dengan banyak orang. Hal tersebut kerap di salahpahami oleh orang-orang pada umumnya. Maka di rasa perlu untuk menyampaikan sebuah gagasan bahwa tidaklah selalu yang berkaitan dengan introvert itu negatif. Mayoritas orang di muka bumi ini berkarakter ekstrovert, sehingga orang-orang introvert sering merasa diperlakukan tidak baik. Masyarakat sekarang ini pro-ekstrovert, bahkan masyarakat melihat karakter introvert sebagai abnormal, dan orang pemalu perlu mendapatkan terapi (Boeree, 2016).

Kepribadian manusia merupakan suatu hal yang tidak bisa dilihat dengan kasat mata, karena di butuhkan pendekatan dan pembelajaran untuk memahami kepribadian introvert. Sehingga proses kreatif dalam pengerjaan visualisasi kepribadian introvert dalam fotografi ekspresi menjadi menarik untuk di bahas. Proses kreatif adalah metode dan landasan teori hingga proses akhir pembentukan karya. Visualisasi kepribadian introvert dengan media fotografi bertujuan untuk memberikan pemahaman tentang kepribadian introvert dengan menampilkan figur-figur manusia dan objek-objek simbolis sebagai representasi introvert. Bahwa pada dasarnya, hal tersebut tidak hanya menarik untuk dibahas, namun akan lebih menarik apabila di visualisasikan dalam sebuah karya fotografi.

\section{Vilhelm Hammershoi}

Vilhelm Hammershoi (1864-1916) adalah seorang pelukis Denmark beraliran impresionis. Karya lukis Vilhelm Hammershoi sebagian besar memiliki kesan puitis, misterius, sepi namun tidak kosong dan kesunyian yang ganjil. Sebagian besar karyanya dibuat berdasarkan realitas atau kejadian yang terjadi di sekitarnya seperti potret aktivitas sehari-hari orangorang di rumahnya yaitu istri dan saudara perempuannya di rumah dengan latar belakang interior rumahnya. Inspirasi yang diambil dari karya ini adalah komposisi lukisan dan faktor internal yang mempengaruhi penciptaan lukisan yaitu kepribadian introvert Vilhelm Hammershoi.

Perbedaan dengan karya yang pencipta buat adalah dari segi media penciptaan karyanya. Vilhelm Hammershoi menggunakan cat minyak, kuas, dan kanvas sebagai media penciptaan karyanya, sehingga terciptalah sebuah lukisan. Sedangkan pencipta 
menggunakan medium fotografi dalam penciptaan karya, sehingga dibutuhkan kamera untuk menangkap atau merekam objek sesuai dengan konsep yang telah dibuat dan perangkat lunak untuk proses editing hingga menjadi karya fotografi.

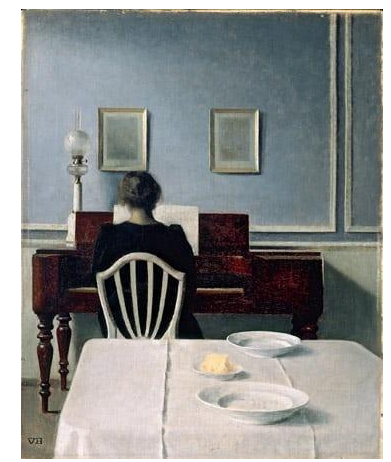

Gambar 1. Interior with Woman at Piano,

Strandgade 30 Vilhelm Hammershoi, 1901, oil on canvas, $55,9 \mathrm{~cm} \times 45,1 \mathrm{~cm}$

(http://theguardian.com/artanddesign/gallery/20 08/jun/25/art.denmark. diakses pada 31 Agustus 2017)

Lukisan pada gambar 1 merupakan salah satu karya Vilhelm Hammershoi yang diberi judul "Interior with Woman at Piano, Strandgade 30". Objek yang ada pada lukisan tersebut adalah Anna Hammershoi, yaitu saudara perempuan Vilhelm Hammershoi. Keterangan yang terlihat pada gambar yaitu objek utama menggunakan dress hitam duduk membelakangi pelukis dengan piano yang ada di depan objek. Terdapat juga meja dengan satu piring berisi makanan dan dua piring kosong di samping piring yang berisi makanan. Komposisi lukisan yaitu objek utama berada di sepertiga bidang.

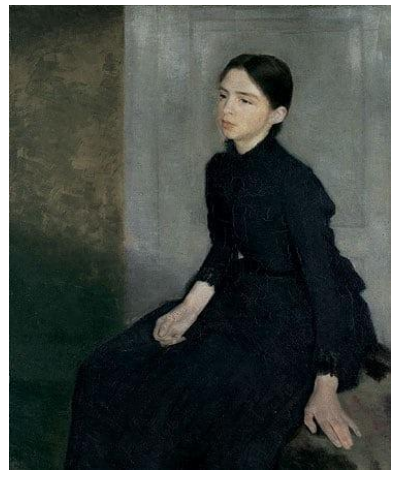

Gambar 2. Potrait of a Young Girl

Vilhelm Hammershoi, 1885; oil on canvas, 112,4 cm x $91,3 \mathrm{~cm}$

(http://theguardian.com/artanddesign/gallery/2008/jun/ 25/art.denmark.

diakses pada 31 Agustus 2017)

(The Guardian, 2017)

Lukisan pada gambar 2 merupakan salah satu karya Vilhelm Hammershoi yang diberi judul "Potrait of a Young Girl". Objek yang di jadikan model pada lukisan tersebut adalah Anna Hammershoi, yaitu saudara perempuan Vilhelm Hammershoi. Tampak pada gambar terlihat objek utama menggunakan dress hitam panjang sembari duduk dengan posisi serong ke kiri dan ekspresi wajah datar memberikan kesan diam dan misterius.

\section{Oleg Oprisco}

Oleg Oprisco adalah seorang fotografer fine art beraliran surealis. Oleg adalah fotografer yang sukses menciptakan foto-foto nuansa dreamy dan terkesan sepi. Karya-karyanya sebagian besar terinspirasi dari kehidupan di sekitarnya. Ke dinamisan dan warna dari foto-fotonya tersebut memberikan inspirasi kepada pencipta dalam proses penciptaan karya fotografi. Perbedaan dengan karya yang diciptakan adalah dari segi proses perwujudan karya. Oleg Oprisco tidak menggunakan digital imaging sedangkan pencipta menggunakan digital imaging dalam proses perwujudan karya.

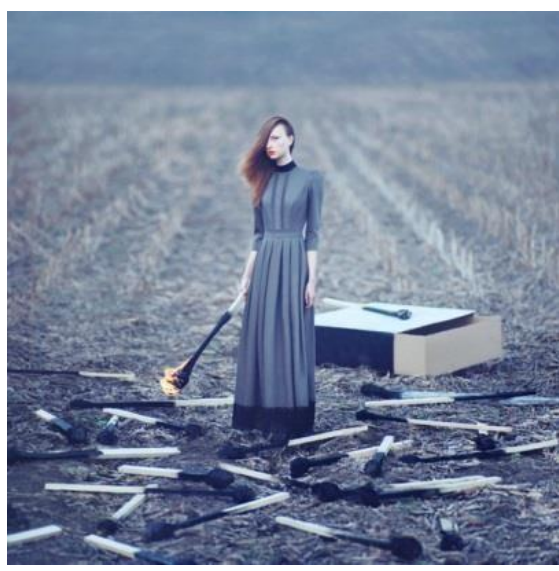

Gambar 3. Untitled

Oleg Oprisco, 2016, instagram

(http://olegoprisco.com. diakses pada 31 Oktober 2017)

(Oprisco, 2017)

Foto pada gambar 3 merupakan salah satu karya Oleg Oprisco yang diberi judul "Untitled". Terlihat objek utama berada tepat di tengah komposisi foto, tampak wanita berdiri dengan satu mata menatap tajam ke arah kamera dengan membawa sebuah korek api yang masih menyala berukuran besar di tangan kanannya, sebagian wajah wanita tertutup oleh rambut. Beberapa korek api yang sudah padam ada di sekeliling objek seakan memberikan kesan kemarahan yang masih tesisa karena api identik dengan kemarahan.

\section{Jane Long}

Jane Long adalah seorang seniman Australia. Karya olah digitalnya yang berseri Dancing with Costica, Jane Long menggunakan foto-foto dari fotografer Rumania, Costică Acsinte yang kemudian 
diolah digital dan diubahnya menjadi sebuah karya bergaya surealis.

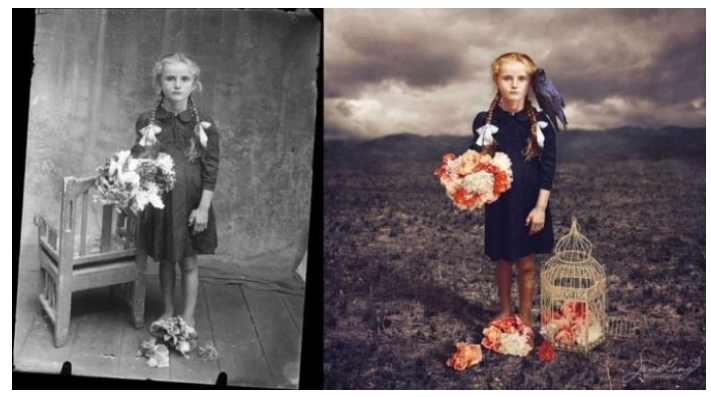

Gambar 4. Corvo

Jane Long, 2016; internet

(www.boredpanda.com/artist-creates-new-imagesfrom-glass-plate-photos/. diakses pada 11 September 2017)

(Panda, 2017)

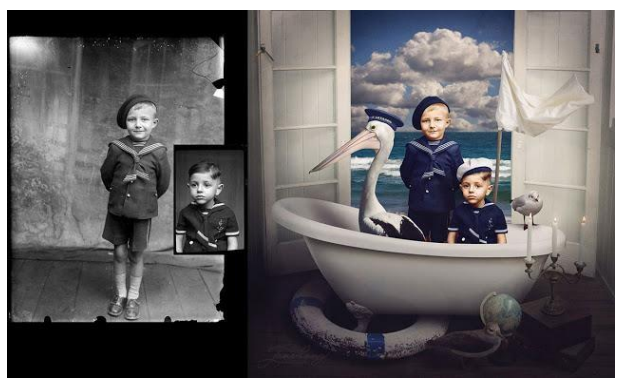

Gambar 5. All Hands on Deck, Jane Long, 2016; intenet

(http://www.boredpanda.com/artist-creates-newimages-from-glass-plate-

photos/,. diakses pada 11 September 2017)

(Panda, 2017)

Foto pada gambar 4 dan gambar 5 merupakan hasil olah digital Jane Long. Foto yang diubahnya adalah foto yang diambil pada masa perang dunia pertama. Saat melihat foto tersebut, Jane Long menginginkan adanya ambiguitas dan cerita di dalamya. Walaupun ia tidak mengetahui cerita dibalik foto tersebut, namun di dalam pikirannya terdapat kisah-kisah yang ia ciptakan sendiri. Karya seni olah digital Jane Long di jadikan sebagai acuan dari segi visual yaitu penambahan elemen-elemen pendukung agar konsep yang di inginkan bisa terwujud. Perbedaan dengan karya yang akan penulis buat adalah dari segi proses pembuatan karya, dimana pencipta berperan juga sebagai fotografer.

\section{Daniel Serva}

Daniel Serva adalah seorang fotografer yang lahir di Venezuela dan sekarang tinggal dan bekerja di Paraguay. Kesulitan dalam mengungkapkan emosi dan perasaannya sehari-hari, menjadikannya membuat proyek 365 yang berarti ia membuat karya selama 365 hari yang menceritakan tentang kehidupannya dalam bentuk karya fotografi surealis yang pada akhirnya akan menjadi sebuah visual diary. Daniel menggunakan dirinya sendiri sebagai model atau disebut self potrait dalam penciptaan karyanya. Semua potret dirinya di penuhi dengan motif dan detail yang surealis tentang dunia imajinasi. Komposisi foto dan proses digital imaging yang dilakukan daniel serva memberikan inspirasi kepada pencipta dalam proses penciptaan karya. Perbedaan dengan karya yang akan pencipta buat adalah dari latar belakang penciptaan karya. Latar belakang penciptaan karya Daniel Serva adalah tentang gambaran emosi dan pengalaman sehari-harinya. Sedangkan latar belakang penciptaan karya pencipta adalah kepribadian manusia.

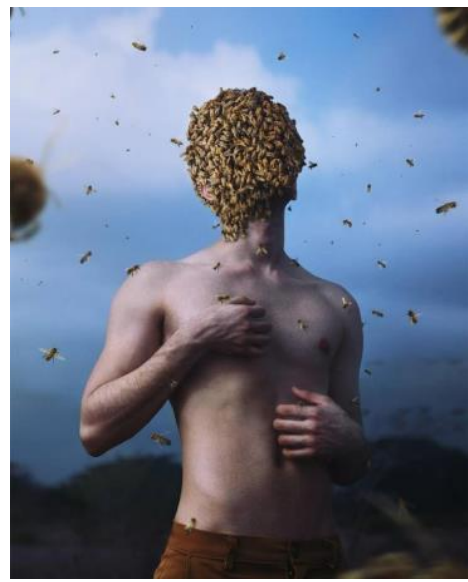

Gambar 6. The (Buzzy) Beekeeper

Daniel Serva, 2017; instagram

(https://www.instagram.com/daniel_serva. diakses pada 29 Mei 2018)

(Serva, 2018)

Foto pada gambar 6 merupakan karya foto Daniel Serva yang diberi judul "The (Buzzy) Beekeeper". Keterangan foto yang terlihat yaitu objek laki-laki telanjang dada, berdiri dengan kepala yang penuh dikerubungi oleh lebah dan beberapa lebah lainnya terbang disekitar tubuh objek dengan posisi kedua tangan objek berada pada bagian dada. Daniel Serva ingin merepresentasikan "setan batin" atau perasaan buruk pada diri manusia. Semua orang memiliki sesuatu yang diperjuangkan secara pribadi dalam pikirannya, sesuatu yang bisa membuat pikiran menjadi berisik berdengung bagai lebah yang banyak. Daniel ingin menyampaikan bahwa semua orang di luar diri kita memiliki masalah, sehingga kita tidak perlu menyerah pada masalah dan kesulitan yang sedang kita hadapi karena ketika orang lain mampu melalui masalahnya, maka kita juga akan mampu melalui masalah yang sedang kita hadapi dan kita pikirkan. 


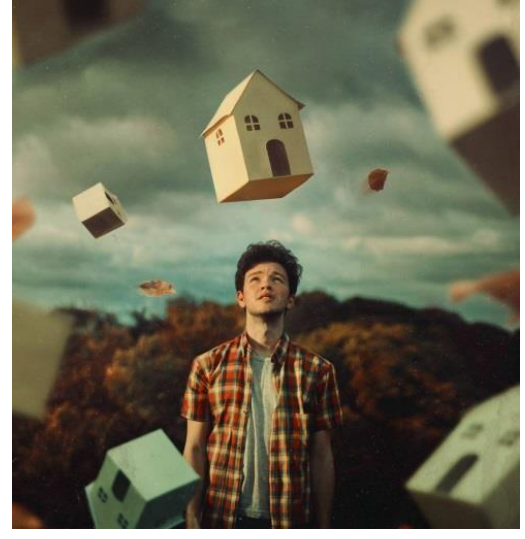

Gambar 7. Nostalgia Daniel Serva, 2017; instagram (https://www.instagram.com/daniel_serva. diakses pada 29 Mei 2018)

(Serva, 2018)

Foto pada gambar 7 merupakan karya foto Daniel Serva yang diberi judul "Nostalgia". Tampak objek laki-laki menggunakan kemeja kotak-kotak dengan kepala agak mendongak dan ekspresi melihat ke atas, dan 5 buah rumah kertas melayang di sekeliling objek. Karya Daniel Serva yang berjudul "Nostalgia" ini menggambarkan mengenai perasaan rindu kepada keluarganya. Rumah kertas yang melayang di sekitar objek merepresentasikan keluarga yang berada jauh di luar jangkauannya. Rumah kertas yang melayang di sekitarnya menggambarkan semua cinta dan kenangan tentang keluarga selalu bersamanya di manapun ia berada.

\section{Landasan Teori Fotografi Ekspresi}

Fotografi semakin berkembang pesat seiring dengan perkembangan zaman. Semua orang bisa dengan mudah mengakses dan mempelajari tentang fotografi. Penciptaan karya fotografi bisa di dasarkan untuk berbagai kepentingan dengan menyebutnya sebagai suatu medium 'penyampai pesan' bagi tujuan tertentu. Soedjono menjelaskan hal tersebut dalam bukunya yang berjudul Potpourri (2007:27), karya fotografi di samping kediriannya yang mandiri juga di manfaatkan bagi memenuhi suatu fungsi tertentu. Sebuah karya fotografi yang dirancang dengan konsep tertentu dengan memilih objek foto yang terpilih dan yang diproses dan di hadirkan bagi kepentingan si pemotretnya sebagai luapan ekspresi artistik dirinya, maka karya tersebut bisa menjadi sebuah karya fotografi ekspresi. Karya foto di maknakan sebagai suatu medium ekspresi yang menampilkan jati diri si pemotretnya dalam proses berkesenian penciptaan karya fotografi seni.

Pendapat lain mengenai fotografi ekspresi juga di kemukakan oleh Kelsey dalam bukunya yang berjudul Photography and The Art of Change bahwa fotografi ekspresi melibatkan berbagai disiplin ilmu, di antaranya lukisan, gambar, dan seni grafis. Menyajikan konten seni ke dalam media fotografi menawarkan sesuatu yang kuno tetapi dengan bentuk yang lebih modern. Ekspresi yang membentuk ide yang berasal dari seorang fotografer dapat di wujudkan dalam bentuk karya foto. Wujud karya tersebut juga dapat di artikan sebagai representasi. Representasi dapat di definisikan lebih jelasnya sebagai penggunaan tanda (gambar, bunyi, dan lainlain) untuk menghubungkan, menggambarkan, memotret, atau mereproduksi sesuatu yang dilihat, di indera, di bayangkan, atau dirasakan dalam bentuk fisik tertentu (Danesi, 2010).

Proses penciptaan karya, ada yang disebut dengan penyelesaian bentuk dengan media yang di sesuaikan. Teknik Montase adalah bentuk penyelesaian penulis dalam proses penciptaan karya. Seperti yang dijelaskan oleh Kusrianti dan Nurcahyo B/W dalam buku Photoshop Photomontage, yaitu montase atau photomontage adalah seni fotografi yang dihasilkan dengan memotong dan menempel beberapa foto lain menjadi sebuah compositphotograph berupa karya foto yang sama sekali baru.

\section{Kepribadian Introvert}

Kepribadian merupakan refleksi diri dan sangat berpengaruh terhadap karakter orang yang bersangkutan. Carl Gustav Jung adalah orang pertama yang menciptakan teori bahwa berdasarkan sikap jiwanya, manusia dapat di golongkan menjadi dua tipe yaitu introvert dan ekstrovert. Sebagaimana seperti yang di ungkapkan oleh Prawira (2013:216), manusia dikatakan bersikap introvert jika sikap kesadaran seseorang mengarah ke dalam dirinya sendiri. Manusia yang mempunyai tipe sikap yang introvert umumnya mempunyai minat pokok pada dunia subjektif yang dijadikan sebagai asas-asas pertimbangan. Berikut adalah sifat-sifat manusia dengan kepribadian introvert menurut pandangan Carl Gustav Jung : Memiliki kecenderungan dan lebih suka "memasuki" dunia imajiner, di samping memiliki kebiasaan untuk merenungkan hal-hal yang bersifat kreatif. Termasuk individu yang produktif dan ekspresi-ekspresinya di warnai oleh perasaan subjektif. Pusat kesadaran diri kepada egonya sendiri dan sedikit perhatian pada dunia luar. Memiliki perasaan halus dan cenderung tidak melahirkan emosi secara mencolok. Mempunyai kebiasaan melahirkan ekspresinya dengan cara yang halus dan tidak terlihat. Memiliki sikap yang umumnya sangat "tertutup" sehingga ketika terdapat konflik hanya disimpan dalam hati. Mereka berusaha untuk menyelesaikan sendiri segala permasalahan, termasuk timbulnya konflik-konflik pada dirinya. Memiliki banyak pertimbangan sehingga ia sering suka mengadakan self analysis dan self critism. Bersifat sangat sensitif terhadap kritik. Pengalaman pribadi bersifat mengendap kuat dalam kenangan, seperti hal-hal yang bersifat pujian atau celaan tentang dirinya. Memiliki sifat yang pemurung dan selalu memiliki kecenderungan bersikap menyendiri.

Berpembawaan lemah lembut dalam bertindak dan bersikap serta mempunyai pandangan idealis. 


\section{METODE PENCIPTAAN}

Metode yang akan digunakan dalam penciptaan ini adalah Observasi, Eksplorasi dan Eksperimentasi. Observasi yang dilakukan adalah melakukan pengamatan tehadap diri sendiri dan orang-orang sekitar pencipta yang memiliki kepribadian introvert. Berdasarkan hasil pengamatan, timbulah ide untuk membuat karya fotografi dengan membahas tentang kepribadian intovert yang pada umumnya di kenal sebagai sosok individu yang tertutup, pendiam, dan jarang bersosialisasi.

Setelah melakukan Observasi selanjutnya adalah Eksplorasi yaitu mengumpulkan data dan informasi mengenai kepribadian introvert dari proses tanya jawab dengan orang-orang introvert kemudian membuat sebuah data mengenai ciri-ciri kepribadian introvert. Studi literatur juga dilakukan untuk menguatkan informasi, sehingga data dan informasi yang didapatkan bisa dipertanggungjawabkan. Selain mencari data secara tertulis, pencipta juga melakukan eksplorasi terhadap karya- karya dua dimensi, baik itu lukisan, gambar, hasil olah digital maupun karya fotografi yang memiliki kesan sepi dan misterius. Eksplorasi terhadap karya dua dimensi berguna untuk memperkaya data visual pencipta, sehingga karya yang akan dihasilkan menjadi lebih berkembang dan ide-ide mengenai visualisasi karya juga semakin beragam.

Setelah melakukan eksplorasi dan semua data telah di dapat, selanjutnya mulai melakukan eksperimentasi. Data dan informasi kepribadian introvert yang didukung oleh studi literatur mengenai kepribadian introvert menjadi sebuah patokan dalam proses penciptaan. Sehingga, dibuat ciri-ciri dari kepribadian introvert yang digunakan sebagai ide dalam konsep penciptaan. Konsep penciptaan dalam bentuk sketsa gambar mempermudah selama proses eksekusi, sehingga karya yang dibuat memiliki patokan dan dasar ide yang jelas. Konsep telah jadi, selanjutnya mempersiapkan kostum, aksesoris, properti pendukung, pencarian dan penentuan model dan dibuat jadwal pemotretan dan penentuan lokasi pemotretan.

Tidak hanya persiapan yang berhubungan dengan visual foto, dalam pengerjaan sebuah foto ada beberapa hal yang harus dipersiapkan yaitu pengadaan alat seperti, kamera, Flash, tripod, Lighting, triger, memori, reflektor, dan lensa sesuai dengan kebutuhan pada saat pemotretan berlangsung. Setelah semua persiapan matang mulai dari konsep dan perencanaan, selanjutnya pemotretan dilakukan sesuai dengan perencanaan yang telah dibuat.

Proses pemotretan selesai dan didapatkan hasil yang sesuai, selanjutnya gambar atau imaji akan melalui proses editing menggunakan software Adobe Photoshop untuk diolah sesuai dengan konsep yang telah dibuat. Penambahan nilai estetis dalam penciptaan ini meliputi retouch foto dan penambahan objek pendukung dengan menggunakan teknik montase. Proses eksperimentasi tidak hanya dilakukan satu atau dua kali, namun berkali-kali sampai mendapatkan hasil karya sesuai dengan harapan pencipta.

\section{PEMBAHASAN}

Pembahasan ini memaparkan perwujudan karya dengan menggunakan penjabaran makna secara tersurat dan tersirat pada foto. Makna tersurat adalah arti yang terkandung secara objektif, seperti objek dan gambar yang terlihat pada foto. Sedangkan makna tersirat adalah makna di balik foto. Sehingga diharapkan pembahasan mengenai karya foto bisa menjadi jelas dan dapat di mengerti. Karya foto pada penciptaan ini dibuat sesuai dengan teori dan data hasil pengamatan dan pemikiran penulis mengenai kepribadian introvert. Model, kostum, background dan properti serta elemen pendukung pada foto berdasarkan pemikiran penulis yang didukung dengan hasil studi literatur.

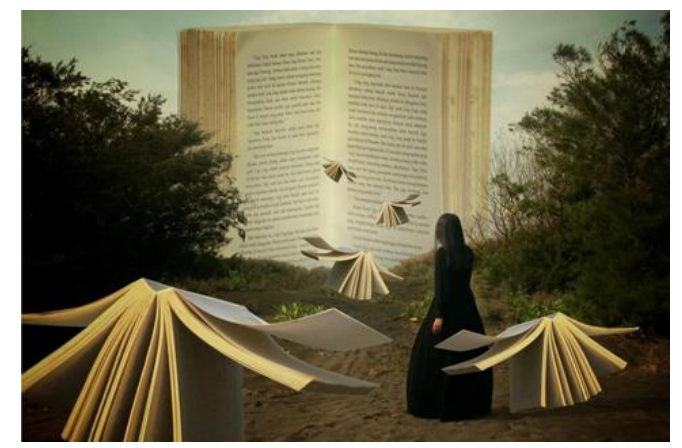

Gambar 8. Karya 1. The World of Books, 2017 Ngesti Limna, $40 \mathrm{~cm}$ x $60 \mathrm{~cm}$, Cetak digital pada canvas glitter

Karya berjudul "The World of Books" merepresentasikan individu introvert adalah orang yang suka membaca buku, hal ini di sebabkan karena orang introvert selalu merasa haus akan ilmu pengetahuan dan ketika mereka membaca buku, mereka akan tenggelam di dalamnya dan merasa seperti masuk ke dalam cerita seperti berada di dunia yang baru. Terlihat pada foto, model wanita dengan pose diam sedang berdiri memakai dress hitam dengan pose membelakangi kamera. Pose Model wanita berdiri dengan latar belakang semak-semak. Sebuah buku besar berdiri dengan posisi terbuka tepat di depan wanita di balik semak belukar. Terdapat lima buah buku melayang di sekitar model. Karya berjudul "The World of Books" menggambarkan sosok introvert yang menyukai membaca buku. Kebiasaannya merenung dan memikirkan banyak hal membuat seorang introvert tertarik dengan banyak hal baru. Orang introvert merasa dengan membaca buku mereka akan menemukan apa yang mereka cari itulah sebabnya kebanyakan orang introvert hobi membaca buku. Pose model yang berdiri membelakangi kamera 
merupakan representasi dari sifat introvert yang antusias ketika belajar hal baru dan tidak ingin diganggu oleh orang lain ketika sedang membaca buku. Wanita memakai dress hitam panjang yang berdiri sendiri menggambarkan sosok introvert yang suka menyendiri, terlebih ketika sedang membaca buku atau melakukan hal yang di sukainya. Buku besar dengan posisi terbuka yang terletak di depan model di representasikan sebagai rasa ingin tahu orang introvert yang begitu besar terhadap hal-hal baru. Sedangkan lima buah buku yang melayang seakanakan terbang di sekitar objek menggambarkan pikiran orang introvert yang bebas seperti terbang bersama imajinasinya. Orang introvert akan merasa nyaman dan sangat menikmati kesendiriannya ketika membaca buku ibarat burung yang terbang bebas di langit. Orang introvert akan merasa seakan-akan imajinasinya terbang bebas mengikuti alur cerita dalam buku.

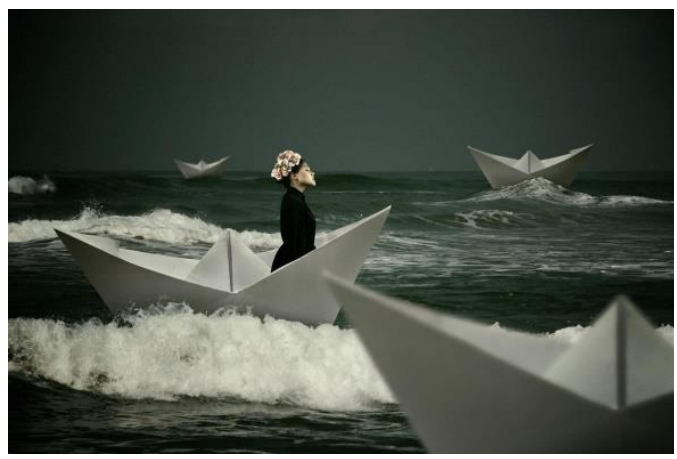

Gambar 9. Karya 2. In My Mind, 2017

Ngesti Limna, $40 \mathrm{~cm}$ x $60 \mathrm{~cm}$, Cetak digital pada canvas glitter

Karya berjudul "In My Mind" merepresentasikan pemikiran orang introvert. Tampak pada foto seorang wanita berdiri di salah satu kapal kertas dengan memakai dress hitam dengan mahkota bunga dikepalanya. Terdapat juga tiga buah kapal kertas di sekitar kapal yang dinaiki model wanita. Empat kapal tersebut mengapung di atas laut yang berombak. Pose tubuh model menghadap ke arah kanan dengan ekspresi wajah memejamkan mata. Tampak pada foto seorang wanita berdiri di atas sebuah kapal merepresentasikan bahwa ketika orang introvert memikirkan suatu hal maka ia seperti terombang-ambing di atas sebuah kapal. Hal ini di karenakan terlalu banyak pendapat yang di pertimbangkan sehingga seringkali orang introvert akan kebingungan dengan pikirannya sendiri.

Kapal kertas merupakan benda yang jika terkena air lama kelamaan akan hancur, hal ini merepresentasikan pendapat yang muncul dari proses berpikir orang introvert yang mudah terpengaruh oleh pendapat lain yang muncul dalam pikirannya sehingga tidak jarang terjadi konflik batin dengan dirinya sendiri. Empat kapal kertas mengapung di atas laut yang berombak. Ombak yang terlihat pada foto menggambarkan pikiran orang introvert yang tidak pernah berhenti berpikir seperti ombak di laut yang terus muncul dan bergerak. Dress hitam yang dipakai oleh model merupakan representasi dari sifat introvert yang selalu menahan emosinya agar tidak terlihat. Walaupun di dalam pikiran orang introvert selalu mengalami konflik dengan dirinya sendiri, namun ia tidak ingin menampilkan emosinya kepada orang lain. Hal tersebut di karenakan orang introvert tidak mau orang lain yang tidak memiliki hak untuk tahu dan ikut campur dalam masalah yang sedang dihadapinya.

Mahkota bunga yang dipakai oleh model merupakan simbol dari usia yang sudah beranjak dewasa. Awal ditemukannya, mahkota bunga atau lebih umumnya disebut flower crown sebagai aksesoris yang digunakan oleh wanita yang sudah memasuki usia dewasa pada saat upacara pernikahan. Sehingga, mahkota bunga yang dipakai oleh model pada foto adalah simbol usia yang sudah menginjak dewasa. Ketika menginjak usia dewasa manusia secara naluriah akan memikirkan berbagai hal dalam hidupnya, hal ini dipengaruhi oleh lingkungan dan pola berpikir yang berkembang. Ekspresi diam model wanita pada foto merepresentasikan sifat introvert yang pendiam.

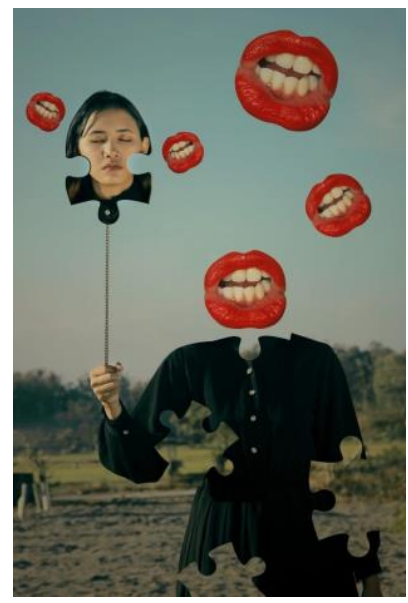

Gambar 10. Karya 15. Lost, 2018

Ngesti Limna, $50 \mathrm{~cm}$ x $75 \mathrm{~cm}$, Cetak digital pada canvas glitter

Karya berjudul "Lost" merupakan bentuk representasi dari sifat kepribadian introvert yang energinya akan hilang ketika bersama dengan orangorang yang terlalu banyak bicara. Tampak pada foto seorang wanita memakai dress hitam memegang sebuah rantai yang diujungnya terdapat kepala berbentuk potongan puzzle. Potongan kepala merupakan bagian tubuh objek wanita yang memegang rantai. Tampak beberapa bagian tubuh wanita seakan lepas seperti potonga puzzle. Terdapat empat buah bibir berwarna merah dengan ekspresi mencibir melayang di sekitar wanita. Pose objek wanita menghadap ke arah kamera dengan pose tangan memegang sebuah rantai yang di ibaratkan sebagai tali balon. Rantai di pilih sebagai simbol 
kekuatan. Tubuh model wanita berlubang seperti puzzle di ibaratkan sebagai jiwa yang lepas dari tubuh. Pose objek wanita merepresentasikan orang introvert yang berusaha bertahan ketika orang lain berkata kasar kepada dirinya seperti pada saat mereka di hujat dan di hina. Pose tangan memegang erat rantai yang ujungnya terdapat kepala model merupakan representasi dari usaha seorang introvert dalam mempertahankan jiwanya tetap berada dalam genggamannya ketika mendapat hujatan dari orang lain.Objek wanita yang memakai baju hitam merupakan representasi dari sifat introvert yang tertutup dan tidak mau diganggu oleh orang lain terutama orang lain yang tidak memiliki hubungan dengannya. Bibir berwarna merah yang melayang di sekitar objek di representasikan sebagai bibir orangorang yang suka menghujat serta berkata-kata menyakitkan. Rantai yang dipegang oleh model wanita merupakan simbol kekuatan untuk mempertahankan jiwa-jiwa yang hilang dalam diri.

\section{KESIMPULAN}

Penciptaan ini merupakan sebuah bentuk perwujudan dari keinginan untuk membuat karya fotografi ekspresi berdasarkan tema tentang kepribadian manusia. Kepribadian introvert menurut Carl Gustav Jung merupakan konsep dasar penciptaan. Imajinasi yang didapat melalui sudut pandang pribadi serta pengalaman empiris juga digunakan dalam proses penciptaan dan pembetukan konsep. Karya penciptaan ini merupakan hasil pemikiran dan ungkapan batin pencipta sebagai orang yang cenderung berkepribadian introvert. Selama proses penciptaan, studi literatur mengenai kepribadian introvert masih sangat kurang. Sebagian besar buku dan artikel yang ditemukan membahas kepribadian secara keseluruhan. Sehingga, teori yang spesifik hanya membahas mengenai kepribadian introvert masih jarang ditemukan. Namun, referensi karya visual mengenai introvert banyak ditemukan baik dari dunia fotografi, ilustrasi, maupun lukisan sehingga proses kreatif eksperimen karya semakin berkembang dan banyak ide baru yang muncul. Hal tersebut terkadang menjadikan proses studi literatur maupun eksperimen karya membutuhkan waktu yang lebih lama karena semakin banyak hal yang harus dipelajari dan diterapkan dalam karya fotografi.

\section{DAFTAR PUSTAKA}

Boeree, C. G. (2016). General Psychology: Psikologi Kepribadian, Persepsi, Kognisi, Emosi, \& Perilaku. Yogyakarta: Ar-Ruzz Media.

Danesi, M. (2010). Pesan, Tanda, dan Makna: Buku Teks Dasar Mengenai Semiotika dan Teori Komunikasi. Yogyakarta: Jala Sutra.

Kelsey, R. (2015). Photography and The Art og Change. United State of America: President and Fellow of Harvard College.

Nurchahyo, A. K. (2010). Photoshop Photomontage. Jakarta: PT. Elex Media Komputindo.

Oprisco, O. (2017). Untitled. Retrieved October 31, 2017, from http://olegoprisco.com

Panda, B. (2017). Historic Glass-Plate Photos from RomaniaRestored And Turned Into Colorful Art. Retrieved September 11, 2017, from http://www.boredpanda.com/artist-creates-newimages-from- glass-plate- photos/

Prawira, P. A. (2013). Psikologi Kepribadian dengan perspektif baru. Yogyakarta: Ar-Ruzz Media.

Serva, D. (2018). The (Buzzy) Beekeeper. Retrieved May 29, 2018, from https://www.instagram.com/daniel_serva.

Soedjono, S. (2006). Pot-pourri fotografi. Jakarta: Universitas Trisakti.

Svarasjati, T. P. (2013). Photagogos Terang-Gelap Fotografi Indonesia. Semarang: Suka Buku.

The Guardian. (2017). Vilhelm Hammershoi at the Royal Academy: the poetry of silence. Retrieved August 31, 2017, from http://theguardian.com/artanddesign/gallery/200 8/jun/25/art.denmak 